\title{
Identification of the Interaction between Insulin-like Growth Factor Binding Protein-4 (IGFBP-4) and Heterogeneous Nuclear Ribonucleoprotein L (hnRNP L)
}

\author{
Mieyoung Choi*
}

Department of Biomedical Sciences, Sunmoon University, Asan, Chungnam 336-708, Korea

Received October 2, 2013 /Revised November 6, 2013 /Accepted November 11, 2013

\begin{abstract}
Heterogeneous nuclear ribonucleoprotein L (hnRNP L) is a major pre-mRNA binding protein and it is an abundant nuclear protein that shuttles between the nucleus and the cytoplasm. hnRNP L is known to be related to many cellular processes, including chromatin modification, pre-mRNA splicing, mRNA export of intronless genes, internal ribosomal entry site (IRES)-mediated translation, mRNA stability, and spermatogenesis. In order to identify the cellular proteins interacting with hnRNP L, this study performed a yeast two-hybrid screening, using a human liver cDNA library. The study identified insulin-like growth factor binding protein-4 (IGFBP-4) as a novel interaction partner of hnRNP L in the human liver. It then discovered, for the first time, that hnRNP L interacts specifically with IGFBP-4 in a yeast two-hybrid system. The authenticity of this two-hybrid interaction of hnRNP L and IGFBP-4 was confirmed by an in vitro pull-down assay.
\end{abstract}

Key words : Heterogeneous nuclear ribonucleoproteins (hnRNPs), hnRNP L, yeast two-hybrid system, Insulin-like growth factor binding protein-4 (IGFBP-4), GST pull-down assay

\section{Introduction}

The heterogeneous nuclear ribonucleoproteins (hnRNPs) are abundant RNA-binding proteins which play important roles in multiple aspects of the biogenesis of mRNA and mRNA metabolism, including activation of transcription, packaging of nascent transcripts into hnRNP particles, regulation of pre-mRNA processing, the transport of mature RNAs to the cytoplasm, regulation of translation, and regulation of mRNA stability [13]. More than 20 hnRNPs have been determined to exist in human nuclei, and are designated hnRNP A1 through U [3]. hnRNPs are able to bind to RNA with differential binding specificities and interact via protein-protein interaction both with themselves and with other protein factors $[12,13]$.

The hnRNP L protein is composed of 558 amino acid residues, and contains four loosely conserved RNP-consensus (CS) RNA-binding domains (RBDs) that bind to CA-rich elements $[3,10]$. hnRNP $L$ was first identified as a nuclear protein. However, it is not restricted to the nucleus, rather

\section{*Corresponding author}

Tel : +82-41-530-2274, Fax : +82-41-530-2939

E-mail : choimy@sunmoon.ac.kr

This is an Open-Access article distributed under the terms of the Creative Commons Attribution Non-Commercial License (http://creativecommons.org/licenses/by-nc/3.0) which permits unrestricted non-commercial use, distribution, and reproduction in any medium, provided the original work is properly cited. shuttles between the nucleus and cytoplasm [16]. hnRNP L has been proposed as a global regulator on the level of mRNA processing, markedly in alternative splicing [15]. It was reported that hnRNP L binds to pre-mRNA processing enhancer of Herpes Simplex Virus thymidine kinase gene and promotes both polyadenylation and nucleocytoplasmic export of intronless mRNAs [6]. hnRNP L was found to specifically interact with the hepatitis $\mathrm{C}$ virus (HCV) internal ribosomal entry site (IRES) and facilitate HCV IRES-mediated translation initiation [8, 11]. It was suggested that hnRNP L plays a novel functional role in RNA stability through binding with high affinity to CA repeats [10]. Moreover, the hnRNP L protein was suggested as a key factor involved in apoptosis, death and growth of spermatogenic cells from functional proteomic studies of azoospermia patients with sertoli cell only syndrome [18].

In order to better understand the function of hnRNP, this study searched for novel binding partners of hnRNP L in human liver cells. hnRNP L was used as a bait in a yeast two-hybrid screening for that purpose. Several independent cDNA clones were identified and their nucleotide sequences and predicted amino acid sequences were analyzed. The nucleotide sequence of some of these clones was identical with that of human IGFBP-4 (Insulin-like growth factor binding protein-4) (GeneBank accession number NM_001552.2). IGFBP-4 is one of the insulin-like growth factor binding proteins (IGFBPs). IGFBP-4 is known to be the protein that me- 
diates cell proliferation by binding to insulin-like growth factor (IGF)-I and IGF-II. It is also known to mediate its actions through a mechanism which is independent of IGFs [22]. In addition, IGFBP-4 has been shown to inhibit DNA synthesis induced by IGF-I in both cancerous and non-cancerous cells [9]. Finally, IGFBP-4 has been implicated predominantly in inhibitory functions, which include reducing cellular proliferation and DNA synthesis as well as inducing apoptosis in a cell type-specific manner [4].

This study showed for the first time that hnRNP L interacts specifically with IGFBP-4 in a yeast two-hybrid system. The authenticity of this interaction between hnRNP L and IGFBP-4 was verified by an in vitro binding assay.

\section{Materials and Methods}

\section{Plasmid constructs}

The plasmids pGBT9 and pACT2 were purchased from Clontech Inc. Plasmids pGBT9/hnRNP L (1 558), pGAD424/ hnRNP L (1 558) and pTM1/hnRNP L were a kind gift from Dr. Sung Key Jang (Department of Life Science, Pohang University of Science and Technology, Korea) [7]. The generation of plasmids pGBT9/hnRNP A1 (1 320) and pGAD424/hnRNP A1 (1 320) was obtained as described previously [12].

For the construction of pACT2/IGFBP4 (2 258), the original clone \#9, which included a partial cDNA of IGFBP4 from nt\#84 to nt\#2094 as an in-frame fusion with GAL4 activation domain, was used as a template for PCR. A fragment of IGFBP4 coding sequence corresponding to amino acids 2-258 was amplified using the following primers: $5^{\prime}$ CCGGAATTCTGCCCCTCTGCCTCGTGGCC3' (forward) and 5'CCGCTCGAGTCACTCTGAAAGCTGTCAGC3' (reverse). The resultant PCR product was digested with EcoRI and $X$ hd, inserted in-frame into the EcoRI- and Xhd-digested pACT2 vector. The construct was then verified by sequencing to exclude possible errors introduced during PCR (Bionex, Korea).

pGBT9/IGFBP-4 (2 258) was created by cloning the DNA fragment from pACT2/IGFBP-4 (2 258) digested with BanHI/ Xhd into pGBT9 vector treated with BamHI/Sall. pTM1/IGFBP-4 (2 258) was constructed by inserting the DNA fragment from pACT2/IGFBP-4 (2 258) treated with EcdRI/ Xhd into similarly digested pTM1 vector [12]. A DNA fragment encoding IGFBP-4 (2 258) was isolated by digestion of pTM1/IGFBP-4 (2 258) with Ncd and Xhd. This in- sert DNA was ligated with similarly treated pCS3-MT vector [19], resulting in a construct pCS3-MT/ IGFBP-4 (2 258). The plasmid pGEX-KG/hnRNP L (141 558) was constructed as described by Park et al. [21].

\section{Yeast two-hybrid screening}

The human liver cDNA library and yeast strains were purchased from Clontech, Inc. Yeast two-hybrid screening [5] was carried out as suggested by the manufacturer's instructions. The plasmid pGBT9/hnRNP L (1 558) and human liver cDNA library were introduced into Saccharomyces cerevisiae strain HF7c (MATa, ura3-52, his3-200, lys2-801, ade2-101, trpl-901, leu2-3, 112, gal4-542, gal80-538, cyh'2 2, LYS2:: GAL1 las $-G A L_{\text {tata- }}-H I S 3$, URA3: $G A L A_{17 \text { mess }}(X 3)-C y C_{\text {tata }}$-laZ). Transformants were selected on triple selectable media (synthetic medium lacking leucine, tryptophan, and histidine) and were subsequently screened for $\beta$ - galactosidase activity using a filter lift assay. After $\mathrm{His}^{+}$transformants were transferred to filter paper, liquid nitrogen was added to the filter to lyse the cells. The filter was then laid on top of another filter paper pre-soaked with Z-buffer $\left(60 \mathrm{mM} \mathrm{Na}_{2} \mathrm{HPO}_{4} / 40\right.$ $\mathrm{mM} \mathrm{NaH}_{2} \mathrm{PO}_{4} / 10 \mathrm{mM} \mathrm{KCl} / 1 \mathrm{mM} \mathrm{MgSO}_{4}$ ) containing 5-bromo-4-chloroindol-3-yl $\beta$-D-galactopyranoside (X-Gal) (20 $\mathrm{ng} / \mathrm{ml}$ ). The color change in the yeast colonies was monitored by keeping filters at $30^{\circ} \mathrm{C}$ for up to $30 \mathrm{~h}$ of reaction time.

\section{Production of recombinant proteins}

E. coli BL21 (DE3) pLysS (Novagen) was transformed with the plasmid pGEX-KG/hnRNP L (141 558) as well as with pGEX-KG vector to obtain unfused GST protein. Transformants were grown at $37^{\circ} \mathrm{C}$ until optical density (OD) at 600 $\mathrm{nm}$ reached 0.5. Expression of the proteins was induced by $0.5 \mathrm{mM}$ Isopropyl- $\beta$-D-thiogalactopyranoside (IPTG) for $6 \mathrm{~h}$ at $27^{\circ} \mathrm{C}$. After harvest, the cells were resuspended in lysis buffer [20 mM Na-phosphate (pH 7.6), $150 \mathrm{mM} \mathrm{NaCl}, 0.5$ $\mathrm{mM}$ phenylmethylsulfonyl fluroride (PMSF), $1 \mathrm{mM} \beta$-mercaptoethanol and $10 \%$ glycerol] and sonicated. After centrifugation, the supernatant was stored at $-70^{\circ} \mathrm{C}$.

\section{In vitro pull-down assays}

The plasmids pTM1/hnRNP L and pCS3-MT/IGFBP-4 (2 258) were employed as templates for in vitro transcription-translation reaction. Radio-labeled hnRNP L and IGFBP-4 were synthesized in a rabbit reticulocyte lysate (Promega) in the presence of $\left[{ }^{35} \mathrm{~S}\right]$-methionine and cysteine 
(Perkin Elmer Life Sciences, Inc.). GST pull-down experiment was performed as described [21].

\section{Results and Discussion}

Identification of a novel interaction partner of hnRNP $L$ by two-hybrid cloning

In order to identify novel interaction partners of hnRNP $\mathrm{L}$, the yeast two-hybrid screening [5] was conducted. The screening procedure utilized the hnRNP L cDNA which was fused to the DNA-binding domain of the yeast transcription factor GAL4 (DB-hnRNP L) as a bait. A human liver cDNA library fused to the GAL4 activation domain was employed as a target. About $2.2 \times 10^{6}$ cotransformants were screened by carrying out the selection in yeast strain HF7c, which contains both HIS3 and Lac Z reporter genes under the control of GAL4-responsive elements. Twenty eight positive colonies revealed both $\beta$-galactosidase activity and histidine prototrophy. Library plasmids recovered from the $\beta$-galactosidase $^{+}$and $\mathrm{His}^{+}$yeast colony were transformed into E. coli JBE181. After bacterial colonies were grown on M63-Leu plates, the amplified library plasmid DNA was extracted. The plasmid DNA was analyzed after restriction digestion. In order to confirm interaction, library plasmids containing the CDNA sequence of the putative interaction partners were retransformed with pGBT9/hnRNP L into the reporter yeast strain. In addition, in order to check for self-activating properties of the corresponding cDNAs, they were reintroduced into the reporter yeast strain with pGBT9 only. The library plasmids that conferred $\mathrm{His}^{+}$and blue color to the reporter yeast strain only in the presence of DB-hnRNP L were further analyzed. The cDNA of these plasmids was sequenced and the sequences were characterized by BLAST analysis. BLAST search confirmed that seven independent clones contain partial human IGFBP-4 cDNA (GeneBank accession number NM_001552.2). The mRNA of IGFBP-4 is composed of 2246 nucleotides and includes a single ORF of 777 nucleotides. This coding sequence, residing in between nt\#313 and nt\#1089, encodes 258 amino acid residues. The size of the insert DNAs of those seven clones was about $2.0 \mathrm{~kb}$-long (Fig. 1). Two of them, clone \#9 and clone \#19, seemed to be identical. They contained the complete ORF of IGFBP-4 fused in-frame to the Gal4 activation domain. In contrast, other clones were found to be inserted out-offrame with the Gal4 activation domain. Clone \#9, which included a partial cDNA of IGFBP-4 from nt\#84 to nt\#2094,

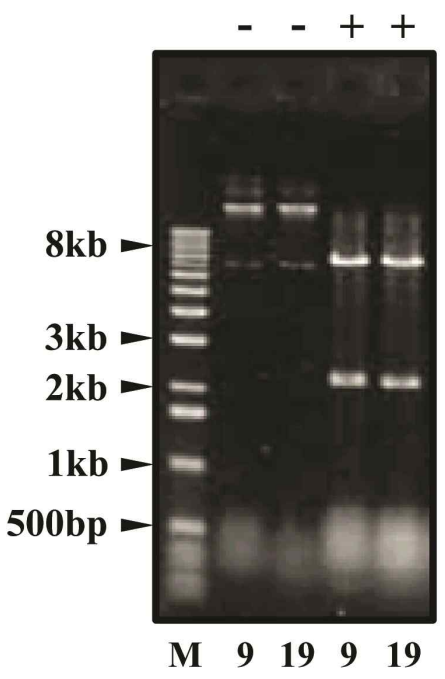

Fig. 1. Analysis of library plasmids. Library plasmids of clone $\# 9$ and $\# 19$ were rescued from the $\beta$-galactosidase ${ }^{+}$and $\mathrm{His}^{+}$yeast colony and transformed into E. coli JBE181. Bacterial colonies were then grown on M63-Leu plate. The plasmid DNAs were extracted and the size of insert DNAs was analyzed on the $0.8 \%$ agarose gel after digestion with EcoRI and $X$ hol (indicated as + ). Undigested plasmid DNAs were marked as -. Size marker was indicated as $\mathrm{M}$.

corresponding 5'UTR, complete ORF, and 3'UTR, was used as a template for PCR. A fragment of the IGFBP-4 coding sequence corresponding to amino acids 2 258 was amplified and ligated into the coding sequence of the Gal4 activation domain of pACT2. The nucleotide sequences of the PCR-amplified inserts were confirmed by sequencing.

In vivo analysis of the interaction between hnRNP $\mathrm{L}$ and IGFBP4

In vivo analysis of protein-protein interaction of hnRNP L and IGFBP-4 was verified after re-transformation of two plasmids into the reporter yeast strain. Visual inspection of activation of the HIS3 and Lac $Z$ reporters showed that hnRNP L interacted with IGFBP-4 (Fig. 2B, Table 1). IGFBP-4 did not induce $\beta$-galactosidase activity in cells that carried only GAL4 DNA-binding domain (Fig. 2C). This result indicates that IGFBP-4 does not have self-activating property. To further confirm the interaction of hnRNP L with IGFBP-4, the plasmid containing the IGFBP-4 cDNA fused to the Gal4 DNA-binding domain was also constructed. The interaction between hnRNP L and IGFBP-4 was then examined. When fusion proteins of DB-IGFBP-4 and Ac-hnRNP L were expressed in the reporter yeast strain, $\mathrm{His}^{+}$and $\beta$-galactosidase activity were demonstrated. (Fig. 2H, Table 1). IGFBP-4 did 
not induce $\beta$-galactosidase activity in cells that carried only GAL4 transcription activation domain (Fig. 2G). These results therefore indicate that hnRNP L specifically interacts with human IGFBP-4 in yeast two-hybrid system regardless

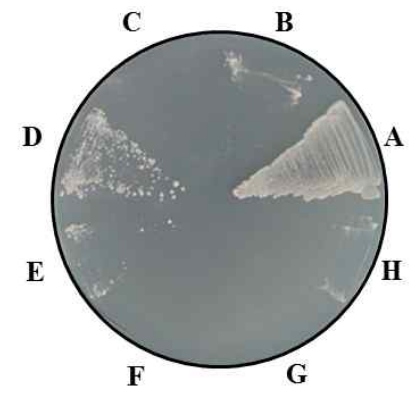
A. pGBT9-hnRNPL + pGAD-hnRNP L
B. pGBT9-hnRNPL + pACT2-IGFBP4
C. pGBT9- + pACT2-IGFBP4
D. pGBT9-IGFBP4 + pACT2-IGFBP4
E. pGBT9-hnRNPA1 + pGAD-hnRNP A1
F. pGBT9 + pACT2
G. pGBT9-IGFBP4 + pACT2
H. pGBT9-IGFBP4 + pGAD-hnRNP L

Fig. 2. Interaction between hnRNP L and IGFBP-4 revealed by yeast two-hybrid analysis. HF7c yeast cells were transformed with the pairs of indicated plasmids. The viability of the transformed yeast cells on Trp ${ }^{-} \mathrm{Leu}^{-} \mathrm{His}^{-}$plates, indicates interactions between the hybrid proteins. The plasmids pGBT9-hnRNP L and pGAD-hnRNP L were used as positive controls. pGBT9-hnRNP A1 and pGADhnRNP A1 were also employed as positive controls.

Table 1. Analysis of the two-hybrid interaction between hnRNP $\mathrm{L}$ and IGFBP-4

\begin{tabular}{|c|c|c|c|}
\hline \multicolumn{2}{|c|}{ Fusion protein } & \multirow{2}{*}{ His } & \multirow{2}{*}{$\beta$-galactosidase } \\
\hline pGBT9- & pACT2 (or pGAD-) & & \\
\hline DB-hnRNP L & Ac-hnRNP L & + & blue \\
\hline DB & Ac & - & white \\
\hline DB-hnRNP L & Ac-IGFBP-4 & + & blue \\
\hline DB- & Ac-IGFBP-4 & - & white \\
\hline DB-IGFBP-4 & Ac-hnRNP L & + & blue \\
\hline DB-IGFBP-4 & Ac & - & white \\
\hline DB-hnRNP A1 & Ac-hnRNP A1 & + & blue \\
\hline DB-IGFBP-4 & Ac-IGFBP-4 & + & blue \\
\hline
\end{tabular}

Reporter yeast strain, HF7c was transformed with the pairs of indicated plasmids. Each colony of transformed yeast cells was streaked onto Trp Leu plates. Yeast cells were then plated onto Trp Leu ${ }^{-} \mathrm{His}^{-}$plates for the viability test. Simultaneously, these yeast cells were also transferred onto filter paper that was then incubated for a $\beta$-galactosidase filter assay. Interaction of hybrid proteins results in the activation of the HIS3 and LacZ reporter genes. Growth in the absence of histidine or blue color change by $\beta$ - galactosidase filter assay is indicated. ' + ' indicates growth and ' - ' indicates 'no growth' on Trp' Leu' ${ }^{-} \mathrm{His}^{-}$plates. of the fused domains. Furthermore, when fusion proteins of DB-IGFBP-4 and Ac-IGFBP-4 were expressed in the reporter yeast strain, $\mathrm{His}^{+}$and $\beta$-galactosidase activity were detected (Fig. 2D). This result suggests that IGFBP-4 exists in oligomeric form as well as monomeric form.

\section{In vitro pull-down assay indicates that IGFBP-4 interacts with hnRNP L}

In order to confirm the physical interaction between two proteins, the examination of protein-protein interaction between hnRNP L and IGFBP-4 was carried out, using in vitro pull-down assay. hnRNP L (141 558) was expressed as a fusion protein with bacterial glutathione S-transferase (GST). The GST protein was used as a negative control. $\left[{ }^{35} \mathrm{~S}\right.$-labeled IGFBP-4 protein was produced from the plasmid pCS3-MT/ IGFBP-4 (2 258), which includes six c-myc epitope tag sequences upstream of the IGFBP-4 coding sequence. They were labeled with $\left[{ }^{35} \mathrm{~S}\right]$-methionine and cysteine by in vitro transcription-translation in reticulocyte lysate. The GST protein or GST-hnRNP L (141 558) fusion protein was bound to glutathione-Sepharose resin. Resin-immobilized GSThnRNP L was incubated with either $\left[{ }^{35} \mathrm{~S}\right]$-labeled IGFBP-4 or, as a control, $\left[{ }^{35} \mathrm{~S}\right]$-labeled hnRNP L (1 558) protein. To exclude the possibility that the protein-protein interaction was mediated by protein-RNA-protein interactions, RNase $A$ and RNase T1 were added to the reaction mixture. After washing the sample, bound GST fusion protein and any associated proteins were dissociated by boiling it in SDS-containing buffer and were analyzed by SDS-PAGE. As shown in Figure 3, GST-hnRNP L (141 558) fusion protein was able to pull-down both radio-labeled hnRNP L and IGFBP-4. On the other hand, these labeled proteins could not be precipitated by GST alone (Fig. 3). Therefore, this study concludes that IGFBP-4 is capable of interacting specifically and physically with hnRNP $\mathrm{L}$ in an in vitro pull-down assay.

IGFBP-4 is one of the insulin-like growth factor binding proteins. Six IGFBPs have been identified so far. IGFBPs regulate the biological activity of IGF, either inhibiting or potentiating its effects by modulating bioavailability of IGFs [2]. IGFBP-4 acts by binding to IGF-I and IGF-II and modulating their biological effects. IGFBP-4 is a very important inhibitory binding protein of the IGF system and inhibits IGF-I activity by sequestering IGFs but cleavage by pregnancy associated plasma protein-A (PAPP-A) protease releases active IGF-I [1]. IGFBP-4 was found to play a role not only as a negative regulator, but also as a positive regulator of IGF-in- 


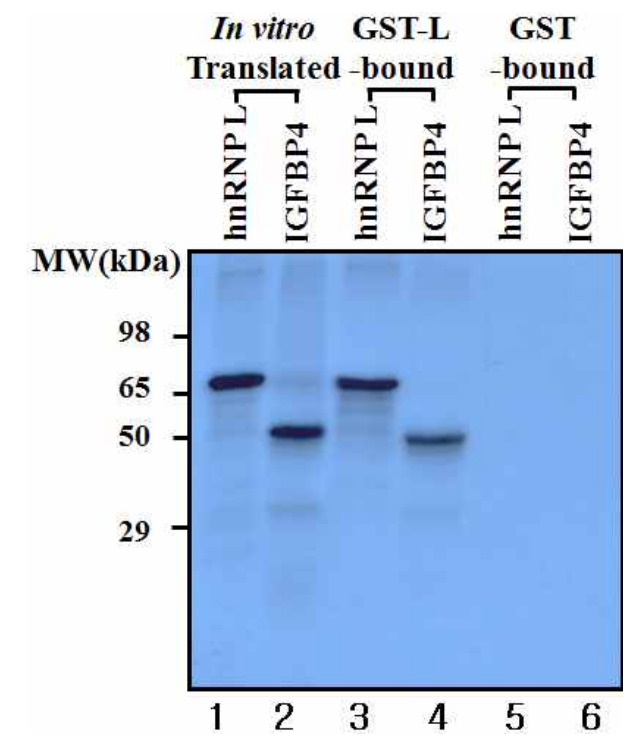

Fig. 3. In vitro binding of hnRNP L to IGFBP-4 in GST pull-down assay. The in vitro translated and $\left[{ }^{35} \mathrm{~S}\right]$-labeled hnRNP L and IGFBP-4 proteins are shown in lanes 1 and 2, respectively. These radio-labeled proteins were incubated with resin-bound GST-hnRNP L (141 558) (lanes 3 and 4) or GST (lanes 5 and 6) in the presence of RNase A and RNase T1. After washing the samples, the resinbound proteins were resolved on 12\% SDS-polyacrylamide gel. Autoradiograph of the SDS-PAGE is shown.

duced cell proliferation and differentiation [20]. Moreover, IGFBP-4 acts independent of IGF-I and IGF-II. It was suggested that IGF-independent activities modulate numerous cellular processes, including cell growth, differentiation, and apoptosis, although the mechanism of the IGF-independent action of IGFBP-4 is not well understood [22].

IGFBP-4 is produced mainly in the liver, but many other tissues, especially neoplastic tissue, produce it, as well [14, 17]. It has been found that most of the endogenously expressed IGFBP-4 was secreted and some cellular IGFBP-4 was also detected in a variety of cells [23]. Cellular IGFBP-4 was identified as slightly bigger than the secreted IGFBP-4, presumably because of the presence of a secretion signal [23]. The function of cellular IGFBP-4 is not yet known. On the other hand, there is accumulated evidence showing the link between IGFBP-4 and a variety of cancers [4]. As a result, IGFBP-4 is rapidly gaining attention as a protein related to the progression of some cancer cells.

Previous studies suggest that hnRNP L is involved in regulating both translation and mRNA stability in the cytoplasm. This regulation is likely to be achieved with the assistance of other cellular factors. The function of cytoplasmic IGFBP-4, in contrast, has not yet been identified. At this moment, the functional consequences of protein-protein interaction between hnRNP L and IGFBP-4 is unknown. A further study of the in vivo interaction between these two proteins in human cells is required to gain insight into the cellular function of this protein complex.

\section{Acknowledgements}

I want to thank Dr. S. K. Jang (Department of Life Science, Pohang University of Science and Technology, Korea) for the generous gift of plasmids pGBT9/hnRNP L (1 558), pGAD424/hnRNP L (1 558) and pTM1/hnRNP L. I am grateful to Hong Gyu Park and Sun-Young Han for their assistance.

\section{References}

1. Bunn, R. C., Green, L. D., Overgaard, M. T., Oxvig, C. and Fowlkes, J. L. 2004. IGFBP-4 degradation by pregnancy-associated plasma protein-A in MC3T3 osteoblasts. Biochem Biophys Res Commun 325, 698-706.

2. Clemmons, D. R. 1997. Insulin-like growth factor binding proteins and their role in controlling IGF actions. Cytokine Growth Factor Rev 8, 45-62.

3. Dreyfuss, G., Matunis, M. J., Pinol-Roma, S. and Burd, C. G. 1993. hnRNP proteins and the biogenesis of mRNA. Annu Rev Biochem 62, 289-321.

4. Durai, R., Davies, M., Yang, W., Yang, S. Y., Seifalian, A., Goldspink, G. and Winslet, M. 2006. Biology of insulin-like growth factor binding protein- 4 and its role in cancer (review). Int J Oncol 28, 1317-1325.

5. Fields, S. and Song, O. 1989. A novel genetic system to detect protein-protein inter-actions. Nature 340, 245-246.

6. Guang, S., Felthauser, A. M. and Mertz, J. E. 2005. Binding of hnRNP L to the pre-mRNA processing enhancer of the Herpes Simplex Virus thymidine kinase gene enhances both polyadenylation and nucleocytoplasmic export of intronless mRNAs. Mol Cell Biol 25, 6303-6313.

7. Hahm, B., Cho, O. H., Kim, J. E., Kim, Y. K., Kim, J. H., Oh, Y. L. and Jang, S. K. 1998. Polypyrimidine tract-binding protein interacts with HnRNP L. FEBS Lett 425, 401-406.

8. Hahm, B., Kim, Y. K., Kim, J. H., Kim, T. Y. and Jang, S. K. 1998. Heterogeneous nuclear ribonucleoprotein L interacts with the $3^{\prime}$ border of the internal ribosomal entry site of hepatitis C virus. J Virol 11, 8782-8788.

9. Hsieh, T., Goegon, R. E., Clemmons, D. R., Busby, W. H. Jr. and Duan, C. 2003. Regulation of vascular smooth muscle cell responses to insulin-like growth factor (IGF)-I by local IGF-binding proteins. J Biol Chem 278, 42886-42892.

10. Hui, J., Reither, G. and Bindereif, A. 2003. Novel functional role of CA repeats and hnRNP L in RNA stability. $R N A$ 9, 931-936.

11. Hwang, B. H., Lim, J. H., Hahm, B. S., Jang, S. K. and Lee, 
S. W. 2009. hnRNP L is required for the translation mediated by HCV IRES. Biochem Biophys Res Commun 378, 584-588.

12. Kim, J. H., Hahm, B., Kim, Y. K., Choi, M. and Jang, S. K. 2000. Protin-protein interaction among hnRNPs shuttling between nucleus and cytoplasm. J Mol Biol 298, 395-405.

13. Krecic, A. M. and Swanson, M. S. 1999. hnRNP complexes: composition, structure, and function. Curr Opin Cell Biol 11, 363-371.

14. Kroc-Grodzicki, B., Ren, N. and Hilf, R. 1993. Insulin-like growth factor-binding proteins in R3230AC mammary tumors of intact and diabetic rats. Endorcinology 133, 23622370.

15. Lee, H. H., Monica, H., Hui, J., Silke, S., Vladimir, B. and Albrecht, B. 2008. Diverse roles of hnRNP L in mammalian mRNA processing : A combined microarray and RNAi analysis. RNA 14, 284-296.

16. Lee, S. Y., Jang, S. K. and Choi, M. 2003. Human hnRNP $\mathrm{L}$ shuttles between nucleus and cytoplasm. Korean J Genetics 25, 141-145.

17. Lewinski, A., Marcinkowska, M., Brzezianska, E., Jeziorowska, A., Wloch, J. and Brzezinski, J. 2004. Expression of insulin-like growth factor I (IGF-I) gene and of genes for IGF-binding proteins 1,2,3,4 (IGFBP-1-IGFBP-4) in non-neoplastic human thyroid cells and in certain human thyroid cancers. Effect of exogenous IGH-I on this expression.
Endorcr Res 30, 47-59.

18. Li, J., Guo, W., Li, F., He, J., Yu, Q., Wu, X., Li, J. and Mao, W. 2012. HnRNP L as a key factor in spermatogenesis: Lession from functional proteomic studies of azoospermia patients with sertoli cell only syndrome. J Proteomics 75, 2879-2891.

19. Loiodice, I., Alves, A., Rabut, G., Van Overbeek, M., Ellenberg, J., Sibarita, J. B. and Doye, V. 2004. The entire Nup107-160 complex, including three new members, is targeted as one entity to kinetochores in mitosis. Mol Biol Cell 7, 3333-3344.

20. Ning, Y., Schuller, A. G. P., Conover, C. A. and Pintar, J. E. 2008. Insulin-like growth factor (IGF) binding protein-4 is both a positive and negative regulator of IGF activity in vivo. Mol Endocrinol 22, 1213-1225.

21. Park, H. G., Yoon, J. Y. and Choi, M. 2007. Heterogeneous nuclea ribonucleoprotein D/AUF1 interacts with heterogeneous nuclear ribonucleoprotein L. J Biosci 32, 1263-1272.

22. Ricort, J. M. 2004. Insulin-like growth factor binding protein (IGFBP) signaling. Growth Horm IGF Res 14, 277-286.

23. Ryan, A. J., Napoletano, S., Fitzpatrick, P. A., Currid, C. A., O'sullivan, N. C. and Harmey, J. H. 2009. Expression of a protease-resistant insulin-like growth factor-binding protein-4 inhibits tumor growth in a murine model of breast cancer. Br J Cancer 101, 278-286.

\section{초록 : IGF결합 단백질-4(IGFBP-4)와 이질 핵 리보핵산단백질 L (hnRNP L)의 상호결합의 식별 \\ 최미영ᄎ \\ (선문대학교 의생명과학과)}

hnRNP L은 pre-mRNA에 결합하는 단백 질들 중에서 핵심이 되는 단백질이다. hnRNP L은 양이 아주 많은 핵 단백질로서 핵과 세포질을 왕복하는 특성을 지니고 있다. 이 단백질은 염색질 변형(chromatin modification), pre-mRNA 스플라이싱, 인트론이 없는 유전자들에서 유래한 mRNA들의 세포질로의 반출(export), IRES-매개성 번역, $\mathrm{mRNA}$ 의 안정성 조절, 정자형성과정 등, 세포 내의 여러 가지 과정에 관여하고 있는 것으로 알려져 있다. 이 논문에서는 hnRNP L과 결합하는 세포 내 단백질을 찾아내기 위하여 사람의 간세포 cDNA library를 사용하여 이스트 two-hybrid 탐색 실험을 수행하였다. 그 결과 사람의 간세포에서 IGFBP-4가 hnRNP L과 상호결합하는 새로운 파트너라는 것을 발견하였다. 본 연구를 통하여 hnRNP L이 이스트 two-hybrid 시스템에서 IGFBP-4와 특이적으로 상호 결합한다는 것을 처음으로 발견하였다. 본 연구에서는 또한 이스트 two-hybrid 시스템에서 hnRNP L이 IGFBP-4와 상호결합한다는 점을 in vitro pull-down 실험을 통하여 재확인하였다. 